\title{
Traumatic Brain Injury in Portugal: Trends in Hospital Admissions from 2000 to 2010
}

\author{
Traumatismo Crânio-Encefálico em Portugal: Tendências em Doentes \\ Internados de 2000 a 2010
}

\author{
Celeste DIAS ${ }^{1}$, João ROCHA², Eduarda PEREIRA ${ }^{1}$, António CEREJO ${ }^{3}$ \\ Acta Med Port 2014 May-Jun;27(3):349-356
}

ABSTRACT

Introduction: Traumatic brain injury has a considerable socio-economic impact, being a major cause of morbi-mortality, often with permanent disability. We sought to characterize health resource utilization of adult traumatic brain injury patients in Portugal between 2000 and 2010.

Material and Methods: Retrospective study of medical records of adult patients with ICD9 diagnostic code of traumatic brain injury included in the National Diagnosis Related Groups Database from 2000-2010. Descriptive statistical analysis was performed and trends during the decade were evaluated.

Results: We analysed 72865 admissions to 111 hospitals, $64.1 \%$ males, mean age $57.9 \pm 21.8$ years (18-107). We found a decrease in number of traumatic brain injury in younger patients and an increase in older ones. The number of traffic accidents decreased and the number of falls increased. There was an increase of moderate to severe traumatic brain injury admissions: $47.2 \%$ in $2000 / 80 \%$ in 2010. Patients admitted in Intensive Care have nearly doubled (15.8\% vs $29.5 \%)$ as well as the number submitted to neurosurgical procedures $(8.2 \%$ vs $15.2 \%)$. Total mortality increased from $7.1 \%$ to $10.6 \%$.

Discussion: The decrease of traumatic brain injury may be associated with the trauma prevention campaigns, road network improvement and health politics. The increase in mortality may be related to better pre-hospital care, enabling more severe cases to arrive inhospital alive, and although treated more frequently in Intensive Care and requiring more neurosurgical procedures, they end up having higher mortality. Also this may be due to an increase in patients' age and worse pre-morbid status.

Conclusion: Traumatic brain injury in Portugal is changing. Although hospital admissions due to global traumatic brain injury have decreased, mortality rate has increased.

Keywords: Intensive Care Units; Brain Injuries; Hospitalization; Portugal.

\section{RESUMO}

Introdução: O traumatismo crânio-encefálico tem um impacto sócio-económico considerável, sendo uma importante causa de mobimortalidade, frequentemente causador de incapacidade permanente. Procuramos caracterizar a utilização dos recursos de saúde de adultos com traumatismo crânio-encefálico em Portugal entre 2000-2010.

Material e Métodos: Estudo retrospectivo de registos de adultos com código ICD9 de traumatismo crânio-encefálico incluídos na Base-de-Dados Nacional de Grupos Diagnósticos Homogéneos de 2000-2010. Realizamos uma análise estatística descritiva e avaliamos as tendências durante a década.

Resultados: Analisamos 72865 admissões em 111 hospitais, 64,1\% do sexo masculino, idade média de 57,9 \pm 21,8 anos (18-107). Encontramos uma diminuição no número de traumatismo crânio-encefálico em pacientes jovens e um aumento nos mais velhos. $\mathrm{O}$ número de acidentes de trânsito diminuiu e o número de quedas aumentou. Houve um aumento de traumatismos crânio-encefálicos moderados-graves internados: 47,2\% em 2000 / 80\% em 2010. O número de admissões em Cuidados Intensivos quase duplicou ( $15,8 \%$ vs $29,5 \%)$, assim como o número de procedimentos neurocirúrgicos efectuados $(8,2 \%$ vs $15,2 \%)$. A mortalidade total aumentou de $7,1 \%$ para $10,6 \%$.

Discussão: A diminuição do traumatismo crânio-encefálico observada pode estar associada com as campanhas de prevenção rodoviária, melhoria da rede rodoviária e políticas de saúde. O aumento da mortalidade poderá ser explicado pelo melhor atendimento pré-hospitalar, permitindo que casos mais graves cheguem ao hospital com vida e, embora tratados com mais frequência em Cuidados Intensivos e exigindo procedimentos neurocirúrgicos, vêm a falecer. Por outo lado, o aumento da idade dos doentes presumivelmente com maiores co-morbilidades associadas ao envelhecimento também estará a contribuir para a maior mortalidade.

Conclusão: O traumatismo crânio-encefálico em Portugal está a mudar. Embora as admissões hospitalares por traumatismo crânioencefálico tenham diminuído, a mortalidade aumentou.

Palavras-chave: Unidades de Cuidados Intensivos; Traumatismos Crânio-Encefálico; Hospitalização; Portugal.

\section{INTRODUCTION}

Traumatic head injury and traumatic brain injury (TBI) are defined as head and brain injuries caused by external trauma. ${ }^{1}$ Together, they are a major cause of consumption of health services as well as for mortality, morbidity and permanent disability, ${ }^{2}$ often considered a silent epidemic with a considerable socio-economic impact world-wide. ${ }^{3} \mathrm{~A}$ sys- tematic review of TBI epidemiology of 14 European countries from 1980-2003, derived an aggregate hospitalized plus fatal TBI incidence rate of about 235/ 100000 personyears, ${ }^{4}$ but there were large variations in the reports. ${ }^{5}$

Over the past 20 years a remarkable progress in the management of $\mathrm{TBI}$, especially in critical care units, has

\footnotetext{
1. Intensive Care Department. Neurocritical Care Unit. Hospital São João. University of Porto. Porto. Portugal.

2. Neurology Department. Hospital Escala. Braga. Portugal.

3. Neurosurgery Department. Hospital São João. University of Porto. Porto. Portugal.

Recebido: 03 de Outubro de 2013 - Aceite: 02 de Fevereiro de 2014 | Copyright @ Ordem dos Médicos 2014
} 
been achieved with periodically revised treatment guidelines available since $1996 .^{6}$

Epidemiological reports from different regions of Europe and United States have revealed changes in trends during the last decades. ${ }^{1,7-10}$ Traumatic head and brain injury prevention and management policies need reliable information about incidence, demographic and etiology. This information is not always readily available, particularly in southern Europe countries like Portugal. Also, epidemiological variations and resource availability need to be accessed to better adapt and reform Health Services and referral systems.

Through this study, the authors intend to provide epidemiological characterization and resource utilization trends of TBI adult patients admitted in Portuguese hospitals from 2000 to 2010 .

Currently, in Portugal, there are no reliable epidemiological estimates of patients with severe TBI admitted to hospital or trends of use of hospital resources, including ICU, and their impact on mortality.

\section{MATERIAL AND METHODS Study design}

For study simplification purposes, traumatic head injury will be encompassed in the designation TBI.

We performed an observational, descriptive study of traumatic brain injury patients in the adult Portuguese population, admitted to the 111 hospitals that composed the National Health Service (NHS) hospitals during the study period. Trauma patients may be first admitted in any of these Hospitals and the admission generally takes place within a relatively short distance of where the accident occurred. Usually, the emergency medical teams that are deployed to trauma care, access the need to transport TBI patients to the major neurosurgical trauma referral centres. During this period, a total of 15 hospitals had Neurosurgical teams available for the treatment of TBI patients. After the acute phase, patients can be transferred back to the hospital of the area of residence for continued care.

\section{Data collection}

We analyzed the medical registry of the National Diagnosis Related Groups (DRG) database of all trauma patients with associated TBI admitted to hospital from January $1^{\text {st }} 2000$ to December $31^{\text {st }} 2010$. Only adult patients (> 18 years) were selected for analysis. Selection of TBI patients was made by diagnosis using the International Disease Classification, 9 $9^{\text {th }}$ Edition (ICD9-CM) with codes 800 until 804 and 850 until 854 .

Due to lack of clinical data on DRG registries, TBI severity classification based on ICD-9 codes could only be made considering skull fracture, duration of loss of consciousness and presence of intracranial lesion due to trauma (contusion, laceration or any kind of haemorrhage). With this limitation in mind, we graded TBI as mild (TBI $1)$, including concussions, with no cranial fractures or intracranial lesions, no loss of consciousness or when loss of consciousness was present with less than 30 minutes duration; moderate to severe (TBI 2-3) if skull fracture was present, loss of consciousness for more than 30 minutes or intracranial lesion due to trauma was present; when ICD-9 codes did not allow classification, TBI severity was deemed unknown.

Registry data collected also included demographic characteristics (age, gender), in-hospital stay duration, mortality and destination after discharge, admission in an ICU or need for neurosurgical procedure. Admissions were considered if patient was discharged after a day. Since data anonymity was an issue, all demographic characteristics were referred to hospital admission episodes and not to individual patients. The enrolled patients were divided into four age groups: 18-40 years, 41-60 years, 61-80 years, and $>80$ years for sub-analysis.

We considered patients to have been admitted to ICUs if it was registered on the DRG infirmary code at any point of their hospitalization, or had an ICD-9 procedure code related to ICU management such as mechanical ventilation, tracheal intubation or tracheostomy $(9604,9605,967 x, 311-$ 312x).

Patients with a neurosurgical procedure were also identified using the ICD-9 procedure codes $(012 x, 013 x$, 014x, 015x, 016, 02x).

TBI etiology was divided into 5 major categories: traffic accidents excluding two-wheeled vehicles (E81x to E825x (except all codes ending in 2, 3, 6 or 7) and E8299); traffic accident involving two-wheel vehicles (E81x to E825x ending in 2, 3 and 6 and E8261); falls (E880x to E888x, E9293, E987x); run-over (E81x to E825x 8261 ending in 7, E8257, E8260, E8270, E8280, E8290); others (all other codes), when a code could not be integrated in the previous categories or was not registered.

\section{Ethics statement}

Due to the observational nature of this study, no randomization or therapeutic intervention was made, and all information was gathered retrospectively. Ethical question surrounding patient identity and confidentiality was resolved before data collection by the Regional Health Administration Services, by removing any data that would allow patient identification or personal information visualization through other data source.

\section{Data analysis and statistics}

The DRG database was provided in digital format in xls format for Microsoft Windows Excel. Descriptive statistics analysis was performed with SPSS software (v.16, SPSS Inc. Chicago, IL).

\section{RESULTS}

We recorded a total of 90406 Emergency Department (ED) admissions from 111 hospitals with a TBI ICD9-CM code. A total of 72865 were adults (> 18 years), with male preponderance $1,8 \mathrm{M}$ : $1 \mathrm{~F}$. Mean age of $57.9 \pm 21.8$ years. Moderate to severe traumatic TBI (TBI 2-3) represented the 
majority of patients, with $1 / 5$ of patients with insufficient data as to grade severity. In-hospital admission of more than one day represented $78.8 \%$ of all patients. Total mortality rate was of $6375(8.7 \%)$ and more than half of patients were discharged home. Almost $25 \%$ of patients were admitted to ICUs and $12.3 \%$ had a neurosurgical procedure performed (Table 1).

\section{Demographic data}

Throughout the decade, there has been a sustained decrease in the number of total TBI admissions (Fig. 1). Mean age has continuously risen, from 52.2 years in 2000 to 65.1 years in 2010 (Table 2), maintaining a male preponderance above $60 \%$ (data not shown).

\section{TBI severity and external causes}

During the study period, there has been a clear tendency for severity increase as shown by the progressive reduction of registered mild $\mathrm{TBI}(\mathrm{TBI}$ 1) and a marked growth of moderate to severe TBI (TBI 2-3) rates. Cases

Table 1 - General characterization of patients and hospital admissions

\begin{tabular}{lc}
\hline TBI hospital admissions (> 18 years) & 72865 \\
\hline Total & $46709(64.1 \%)$ \\
Male & $57.9 \pm 21.818-107 \mathrm{yr}$ \\
Age - mean \pm SD and range (years) & $12112(16.6 \%)$ \\
TBI severity & $45991(63.1 \%)$ \\
Mild TBI (TBI 1) & $14762(20.3 \%)$ \\
Moderate to severe TBI (TBI 2-3) & $9.3 \pm 19.1(0-1048)$ \\
Unknown & $12.4 \pm 22.4(0-1048)$ \\
Hospital length of stay (total) - mean \pm SD and range (days) & $17964(24.7 \%)$ \\
Hospital length of stay (TBI 2-3) - mean $\pm S D$ and range (days) & $8988(12.3 \%)$ \\
ICU admissions (total) & $6375(8.7 \%)$ \\
Neurosurgical procedures (total) & $42431(58.2 \%)$ \\
Mortality & $23136(31.8 \%)$ \\
Home discharge & $923(1.3 \%)$ \\
Other institutions & \\
Otherlunknown & \\
\hline
\end{tabular}



Figure 1 - Variation of TBI hospital admissions by age group from 2000 to 2010. 


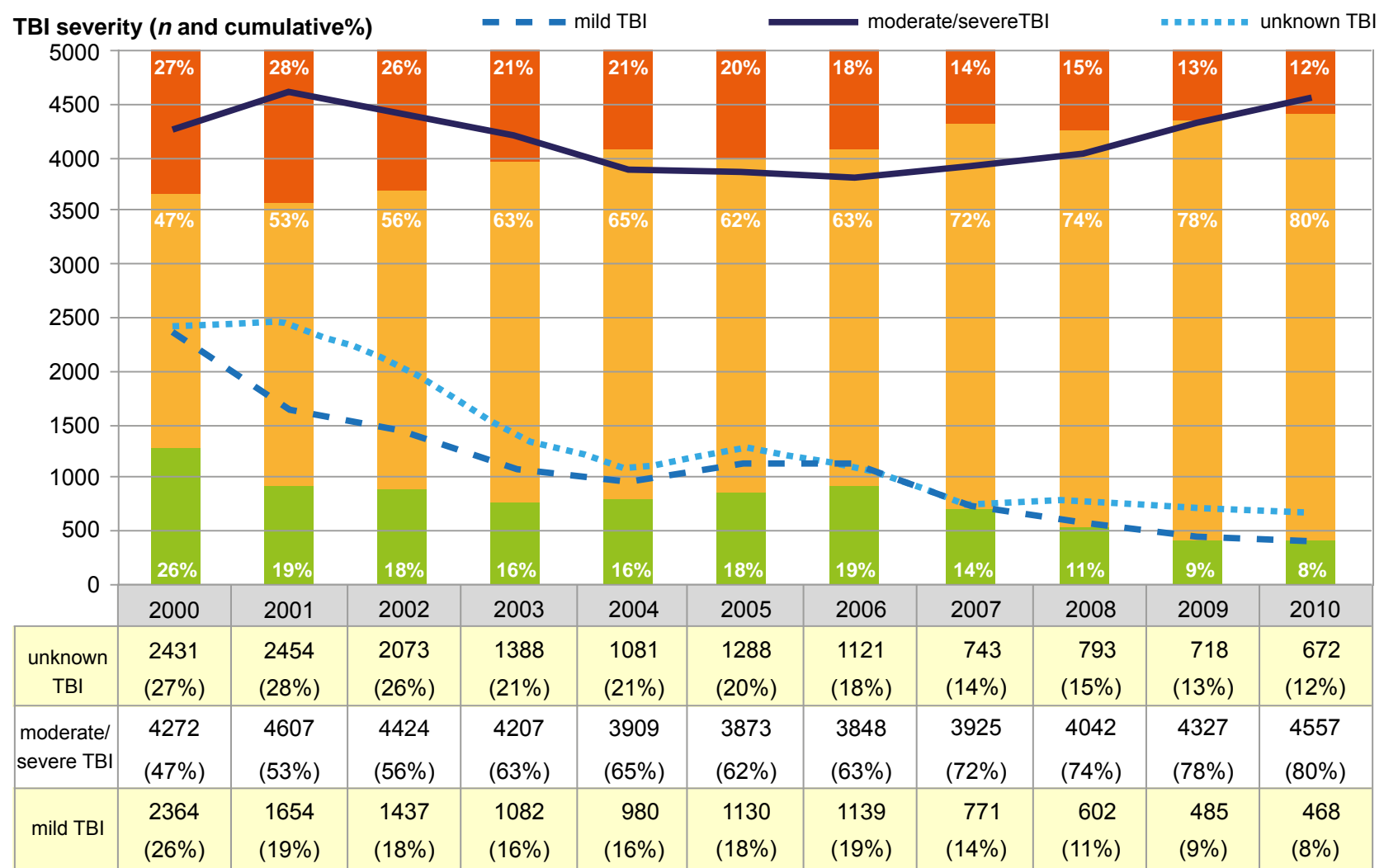

Figure 2 - TBI severity per year (total number and cumulative rate).

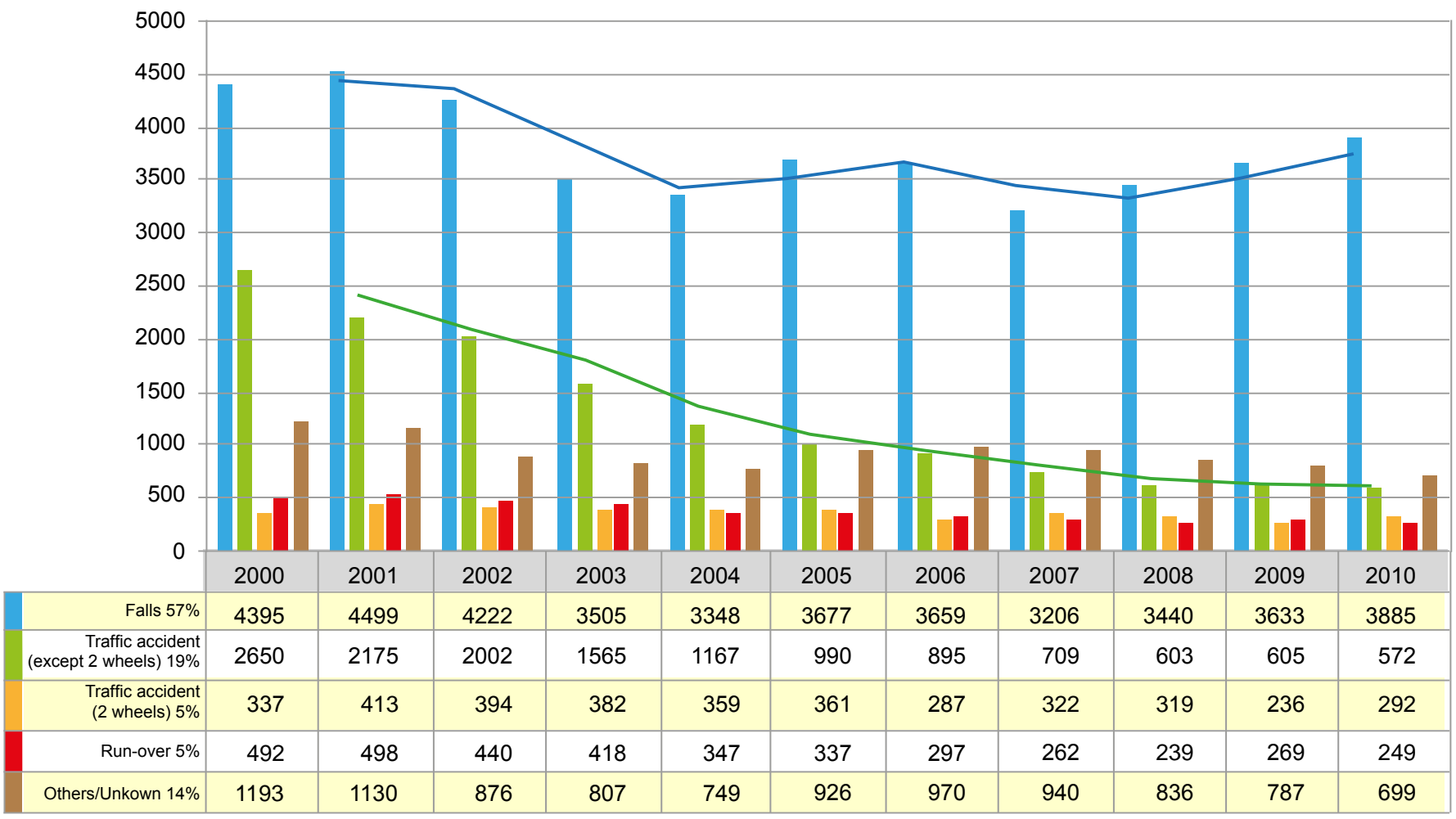

Figure 3 - External cause of TBI per year. 
Table 2 - TBI demographics and management (Hospital length of stay, ICU admission and neurosurgical procedures) and mortality per year

\begin{tabular}{lcccccc}
\hline Year & Gender (Male) & $\begin{array}{c}\text { Mean Age } \\
\mathbf{\pm} \text { SD }(\mathbf{y r})\end{array}$ & $\begin{array}{c}\text { Hospital lenght } \\
\text { of stay (days } \pm \text { SD) }\end{array}$ & $\begin{array}{c}\text { ICU } \\
\text { admission }\end{array}$ & $\begin{array}{c}\text { Neurosurgical } \\
\text { procedure }\end{array}$ & $\begin{array}{c}\text { Total Mortality } \\
\text { and rate }\end{array}$ \\
\hline $\mathbf{2 0 0 0}$ & $596(65.7 \%)$ & $52.2 \pm 21.8$ & $6.6 . \pm .12 .1$ & $1432(15.8 \%)$ & $742(8.2 \%)$ & $641(7.1 \%)$ \\
$\mathbf{2 0 0 1}$ & $5752(66.0 \%)$ & $53.7 \pm 22.0$ & $7.9 \pm 16.9$ & $1846(21.2 \%)$ & $779(8.9 \%)$ & $602(6.9 \%)$ \\
$\mathbf{2 0 0 2}$ & $5174(65.2 \%)$ & $54.6 \pm 22.0$ & $7.8 \pm 17.3$ & $1880(23.7 \%)$ & $647(8.2 \%)$ & $632(8 \%)$ \\
$\mathbf{2 0 0 3}$ & $4365(65.4 \%)$ & $56.4 \pm 22.0$ & $9.3 \pm 17.0$ & $1790(26.8 \%)$ & $746(11.2 \%)$ & $617(9.2 \%)$ \\
$\mathbf{2 0 0 4}$ & $3937(65.9 \%)$ & $56.9 \pm 21.8$ & $9.8 \pm 23.6$ & $1543(25.8 \%)$ & $846(14.2 \%)$ & $572(9.6 \%)$ \\
$\mathbf{2 0 0 5}$ & $3993(63.5 \%)$ & $58.5 \pm 21.5$ & $9.3 \pm 19.6$ & $1579(25.1 \%)$ & $851(13.5 \%)$ & $523(8.3 \%)$ \\
$\mathbf{2 0 0 6}$ & $3763(61.6 \%)$ & $58.6 \pm 21.4$ & $9.3 \pm 18.5$ & $1449(23.7 \%)$ & $805(13.2 \%)$ & $519(8.5 \%)$ \\
$\mathbf{2 0 0 7}$ & $3436(63.2 \%)$ & $61.0 \pm 20.9$ & $11.3 \pm 22.6$ & $1581(29.1 \%)$ & $921(16.9 \%)$ & $530(9.7 \%)$ \\
$\mathbf{2 0 0 8}$ & $3399(62.5 \%)$ & $62.6 \pm 20.9$ & $11.2 \pm 21.4$ & $1572(28.9 \%)$ & $910(16.7 \%)$ & $551(10.1 \%)$ \\
$\mathbf{2 0 0 9}$ & $3442(62.2 \%)$ & $64.6 \pm 20.3$ & $11.6 \pm 20.6$ & $1613(29.2 \%)$ & $874(15.8 \%)$ & $583(10.5 \%)$ \\
$\mathbf{2 0 1 0}$ & $3487(61.2 \%)$ & $65.1 \pm 20.0$ & $11.1 \pm 22.4$ & $1679(29.5 \%)$ & $867(15.2 \%)$ & $605(10.6 \%)$ \\
\hline
\end{tabular}

impossible to be classified through registry (unknown TBI) have diminished considerably (Fig. 2).

Considering external causes of TBI, falls were the most frequent cause of TBI throughout the years and the only etiology to register a considerable increase in frequency in recent years. Two-wheeled traffic accident maintained around a $5 \%$ frequency but a considerable and continuous decrease was noticed in all other causes, especially in traffic accidents. Unclassified causes of TBI also decreased throughout the study period (Fig. 3).

\section{Management and mortality}

As previously mentioned, total in-hospital admissions have decreased (Fig. 1), but duration of hospitalization, ratio of ICU treated patients and patients submitted to neurosurgical procedures has almost doubled (Table 2). Total mortality rate in ICU treated patients was $21.9 \%$ and in patients submitted to neurosurgical procedure was $16.7 \%$ (data not shown in table). Mortality according to TBI severity was 1.1\% (130 patients) for TBI 1, 12.9\% (5 951 patients) for TBI 2-3 and 2.0\% (294 patients) in the unknown severity class (data not shown). A slight increase in total mortality rates was noticed throughout the years (Table 2).

\section{Analysis by age group}

On age sub-analysis TBI was more frequent in the 61-80 group, followed by $18-40,41-60$ and older than 80 years. Male preponderance is only inverted in patients older than 80 years. Hospitalization duration is also higher in the 61-80 group and TBI severity seems to increase in the eldest groups, as happens with mortality. Traffic accidents decreased in older age groups and falls have a considerably higher expression, being the main cause of TBI in patients > 80 years. Rate of ICU admissions decreased with age, but were never under $20 \%$. Inversely, neurosurgical procedures are increasingly performed in older age groups. The rate of home discharge also increased with age (Table 3 ).

The age distribution along the decade is shown in Fig. 1, with an important decrease in TBI numbers in younger age groups and an increase in the elder.

\section{DISCUSSION}

\section{TBI in-hospital admissions - Demographics}

The results of our study clearly show that TBI in Portugal is evolving and there are some identified trends that may be important for Health Services planning and organization. We report a clear decrease in total number of TBI in hospital admissions, confirming trends already demonstrated in other European countries..$^{5,8}$ Male preponderance is maintained throughout the decade as expected when comparing other population based studies. ${ }^{2,5,11}$ An exception to this was found in the age group $>80$ years-old. Here we find a female preponderance, perhaps due to higher life expectancy of women and, therefore, a larger contribution in the composition of older age groups. ${ }^{12}$

Mean age of our population (57.9 years) was higher than reported in other European studies, although most of them only included severe TBI patients. ${ }^{5,7,9}$ This fact may be explained because mean age was calculated taking into account all hospital admissions without excluding readmissions or hospital transfers, since ethical criteria did not allow us to identify duplications in the data base. We point out that ageing of Portuguese population during the last decade, with an important demographic pyramid inversion ${ }^{13}$ may have also contributed to this finding. Finally, by including all grades of TBI and excluding pediatric population, mean age was biased to higher values. Although an incidence analysis was not possible in our study, reports of a trend inversion, with increased incidence in older age groups and decrease in younger ones has also 
Table 3 - TBI Characterization ( $n, \%)$ by age group

\begin{tabular}{|c|c|c|c|c|}
\hline Age group (years) & $18-40$ & $41-60$ & $61-80$ & $>80$ \\
\hline Total & $19553(26.8 \%)$ & $16166(22.2 \%)$ & $24690(33.9 \%)$ & 12456 (17.1\%) \\
\hline Gender male & $15594(79.8 \%)$ & $11960(74 \%)$ & $14264(57.8 \%)$ & $489(39.3 \%)$ \\
\hline Hospital lengh of stay (days) & $8.8 \pm 22.8$ & $9.5 \pm 19.3$ & $9.7 \pm 17.6$ & $9.1 \pm 15.2$ \\
\hline \multicolumn{5}{|l|}{ TBI severity } \\
\hline Mild TBI (TBI 1) & $374(19,2 \%)$ & $2855(17,7 \%)$ & $3556(14,4 \%)$ & $1954(15.7 \%)$ \\
\hline Moderate to severe TBI (TBI 2-3) & $10583(54,2 \%)$ & $9891(61,1 \%)$ & $16946(68,6 \%)$ & $8571(68.8 \%)$ \\
\hline Unknown & $5223(26,7 \%)$ & $3420(21,2 \%)$ & $4188(17,0 \%)$ & $1931(15.5 \%)$ \\
\hline \multicolumn{5}{|l|}{ External Cause } \\
\hline $\begin{array}{l}\text { Traffic accident } \\
\text { excluding } 2 \text { wheel vehicles }\end{array}$ & $7687(39,3 \%)$ & $3229(20 \%)$ & $2607(10,6 \%)$ & $410(3.3 \%)$ \\
\hline $\begin{array}{l}\text { Traffic accident } \\
\text { with } 2 \text { wheels vehicles }\end{array}$ & $2140(10,9 \%)$ & $886(5,5 \%)$ & $606(2,5 \%)$ & $70(0.6 \%)$ \\
\hline Falls & $5405(27,6 \%)$ & $8417(52,1 \%)$ & $17203(69,7 \%)$ & $10444(83.8 \%)$ \\
\hline Run-over & $849(4,3 \%)$ & $987(6,1 \%)$ & $1616(6,5 \%)$ & $396(3.2 \%)$ \\
\hline Other & $3249(16,6 \%)$ & $2382(14,7 \%)$ & $2232(9 \%)$ & $884(7.1 \%)$ \\
\hline Unknown & $233(1,1 \%)$ & $265(1,6 \%)$ & $426(1,7 \%)$ & $252(2 \%)$ \\
\hline ICU admission & $5366(27,4 \%)$ & $4257(26,3 \%)$ & $5779(23,4 \%)$ & $2562(20.6 \%)$ \\
\hline Neurosurgical procedure & $1800(9,2 \%)$ & $1816(11,2 \%)$ & $3589(14,5 \%)$ & $1783(14.3 \%)$ \\
\hline Mortality & $1241(6,3 \%)$ & $1131(7 \%)$ & $2344(9,5 \%)$ & $1659(13.3 \%)$ \\
\hline Home discharge & $10715(54,8 \%)$ & $9254(57,2 \%)$ & $14568(59 \%)$ & 7456 (59.9\%) \\
\hline
\end{tabular}

been reported in northern Europe,${ }^{10}$ rendering our findings, in an older population, more credible.

\section{TBI in-hospital admissions (severity, length of stay and external causes)}

Accompanying the previous reported demographic trend, there seems to be an increase in TBI severity with moderate to severe TBI (TBI 2-3) admitted to hospital reaching $80.0 \%$ in 2010 . This may be associated not only with the higher number of TBI in older patients, ${ }^{10}$ but also to a more efficient pre-hospital emergency care as well as better institutional referral. Thus, more patients with severe TBI, who would have previously died before arriving at hospital, are now being admitted and treated.

As expected and presented in Table 1, the mean length of stay of TBI 2-3 patients is higher than total mean length of stay. Hospital length of stay has increased considerably and an explanation may also be found in the increasing age and severity of TBI patients. This trend is in accordance to data previously reported. ${ }^{10}$

External causes of TBI have changed over the study period. An increase in falls may be explained by an older, ailing population whereas a decrease in traffic accidents, ${ }^{14}$ where typically younger age groups would be at greater risk of TBI, may be related to the improvement of traffic conditions and road safety. Similar results have been previously published. . $^{7-9,15}$

TBI in-hospital admissions - Management and mortality

Total mortality increased during the study period despite more patients being treated in ICUs or submitted to neurosurgical procedures in 2010 in comparison to 2000. There was an expected increase in mortality in keeping with TBI severity. The unknown TBI severity patients only had a $2.0 \%$ mortality, similar to the TBI 1 mortality, which leads us to speculate that this group may share more characteristics with TBI 1 patients, than with TBI 2-3. This trend was also reported in a recent multi-centre study. ${ }^{7}$ ICU mortality was higher than global mortality as can be expected due to the severity of TBI. Better treatment did not mean less mortality. The increase of age and consequently comorbidities may have promoted a raise in mortality, despite optimization of treatment and surgical intervention ${ }^{15}$. When compared with a European study of severe TBI, ${ }^{9}$ our ICU mortality was similar $(31.7 \%$ vs $29.5 \%)$. The comparison, however, is deficient due to methodological differences. The increase in ICU admissions and use of neurosurgical procedures in treating $\mathrm{TBI}$ may be responsible in part for the increase in 
length of hospital stay noted during the period evaluated.

Although mortality increased throughout this period, current treatment options, including implementation of clinical practice guidelines, have proven to benefit survival and outcome. $^{6}$ So, presumably, severe TBI patients that survive do so in better conditions and longer. Also contributing to this may be the technological developments in health services encountered in the first decade of this century and the rise in their consumption. As severity of TBI patients admitted to hospital increases, so does the availability of these resources, permitting treatment of patients in a more differentiated environment.

In our analysis there was a slight reduction in ICU admissions with older age. The majority of ICUs are not dedicated solely to neurologic patients; thus, the investment in older TBI patients may be secondary when comparing younger patients with other ICU manageable conditions. Rates of neurosurgical procedures, however, increased with age. A possible explanation may be found not only in the higher availability of resources but also by the increasing severity of TBI demanding surgical intervention.

Finally, although severity and mortality is higher in older patients, the proportion of home discharge increases with age. This could be partly justified by a probability of a worse functional recovery after the injury.

\section{Final remarks}

To date, this is one of the few studies that provides an analysis of the evolution of TBI in Portugal, and indeed it identified trends in the population composition and TBI etiology, as well as revealing an increase in the number of patients treated with more intensive and invasive modalities. The authors stress the large cohort, including data from 111 hospitals in a period of 11 years.

The importance of this database revision is concerned about reporting epidemiologic evidence that is lacking, especially in southern European countries. In spite of this, some limitations to the analysis must be addressed. First, this is an observational study with retrospective analysis of the DRG database that collects coded information of clinical records. The diagnostic and procedural information was based on ICD-9 codes, which can have several levels of detail, depending on the quality of information provided to the encoder and the number of encoders involved; during the 11 years thousands of encoders were involved in the process. Nevertheless, across the years, we noticed a reduction in the number of 'unknown severity' when classifying TBI that may be associated with an improvement in the quality of registry. It has been reported that codification errors tend to under identify moderate to severe cases of TBI. ${ }^{16}$ In our study, with ICD-9, it seems that the opposite happened. We may argue that some multiple trauma patients may have mild TBI or concussion that was neglected by the encoder faced with other more severe diagnosis. Also, patients that recur to ED due to accidents or other events may also have minor head injuries that are under-reported.

Since we didn't have access to validated severity score scales, our severity grading system was oriented by the clinical characteristics encoded, including intracranial injury, presence of bone fracture and duration of loss of consciousness and was based on other international grading scales.

Bearing all these considerations in mind, the data collected must be analysed cautiously. Our interpretation was based on the trends over the years and not on absolute frequencies. Most studies address only severe TBI or are single-hospital based thus limiting the understanding of the epidemiology of this 'silent epidemic'. ${ }^{3}$ In an effort to provide a more complete and real picture of TBI in Portugal, our study attempted to include all adult patients admitted to all hospitals of the Portuguese National Health Services during the first decade of the $21^{\text {st }}$ century.

\section{CONCLUSION}

In conclusion, our work was based on a large cohort with a broad study period, and provided information that until now was missing. During the decade 2000-2010, TBI hospital admissions have decreased in frequency but mean age increased. Trends in etiology of TBI are shifting from traffic accidents to falls, manifesting the need to pay special attention to older age groups and implementing preventive measures to reduce TBI. Primary prevention of road accidents seems to be working, but we need to improve global accessibility for old people. Utilization of ICU resources and neurosurgical procedures is more widespread but mortality rates have also grown. During the study period, mortality rates have increased, possibly due to the increase of TBI severity, but also Portuguese pre-hospital care improved resulting in previously lethal cases arriving alive at Hospital and, although treated more frequently in ICUs and requiring more neurosurgical procedures, still they end up having higher mortality. In the future, a better quality of registry and codification may lead to collection of data that will permit not only evaluation of trends but also to determine precise frequency, incidence and severity needed to better adjust resources to our population.

\section{ACKNOWLEDGMENT}

The authors wish to thank the collaboration of the Health Systems Central Administration and Northern Regional Health Administration for providing us with the data in which this study was based.

\section{CONFLICTS OF INTEREST}

None stated.

\section{FUNDING SOURCES}

No funding was provided to conduct this study. 


\section{REFERENCES}

1. Ragnarsson KT. Traumatic brain injury research since the $1998 \mathrm{NIH}$ Consensus Conference: accomplishments and unmet goals. J Head Trauma Rehabil. 2006;21:379-87.

2. Corso P, Finkelstein E, Miller T, Fiebelkorn I, Zaloshnja E. Incidence and lifetime costs of injuries in the United States. Inj Prev. 2006;12:212-8.

3. Goldstein M. Traumatic brain injury: a silent epidemic. Ann Neurol. 1990;27:327.

4. Tagliaferri F, Compagnone C, Korsic M, Servadei F, Kraus J. A systematic review of brain injury epidemiology in Europe. Acta Neurochir. 2006;148:255-68

5. Andelic N, Anke A, Skandsen T, Sigurdardottir S, Sandhaug M, Ader T, et al. Incidence of hospital-admitted severe traumatic brain injury and inhospital fatality in Norway: A National Cohort Study. Neuroepidemiology. 2012;38:259-67.

6. Haddad SH, Arabi YM. Critical care management of severe traumatic brain injury in adults. Scand J Trauma Resusc Emerg Med. 2012;20:12.

7. Andriessen TM, Horn J, Franschman G, van der Naalt J, Haitsma I, Jacobs B, et al. Epidemiology, severity classification, and outcome of moderate and severe traumatic brain injury: a prospective multicentre study. J Neurotrauma. 2011;28:2019-31.

8. Masson F, Thicoipe M, Aye P, Mokni T, Senjean P, Schmitt V, et al. Epidemiology of severe brain injuries: a prospective population-based study. J Trauma. 2001;51:481-9.

9. Rosso A, Brazinova A, Janciak I, Wilbacher I, Rusnak M, Mauritz W. Severe traumatic brain injury in Austria II: epidemiology of hospital admissions. Wien Klin Wochenschr. 2007;119:29-34.

10. Koskinen S, Alaranta H. Traumatic brain injury in Finland 1991-2005: a nationwide register study of hospitalized and fatal TBI. Brain Inj. 2008;22:205-14.

11. Leibson CL, Brown AW, Ransom JE, Diehl NN, Perkins PK, Mandrekar $\mathrm{J}$, et al. Incidence of traumatic brain injury across the ful disease spectrum: a population-based medical record review study. Epidemiology. 2011;22:836-44

12. PORDATA.pt. Base de Dados Portugal Contemporâneo; [Accessed 2013 Feb 25]. Available at: http://pordata.pt/Europa/Esperanca+de+vid $\mathrm{a}+\mathrm{a}+$ nascenca+total+e+por+sexo-1260.

13. PORDATA.pt. Base de Dados Portugal Contemporâneo; [Accessed 2013 Feb 25]. Available at: http://pordata.pt/Europa/Populacao+reside nte+idade+media-2265

14. PORDATA.pt. Base de Dados Portugal Contemporâneo; [Accessed 2013 Feb 25]. Available at: http://pordata.pt/Portugal/Acidentes+de+via cao+com+vitimas++feridos+e+mortoss+++Continente-326.

15. Flaada JT, Leibson CL, Mandrekar JN, Diehl N, Perkins PK, Brown AW, et al. Relative risk of mortality after traumatic brain injury: a populationbased study of the role of age and injury severity. J Neurotrauma. 2007;24:435-45.

16. Shore AD, McCarthy ML, Serpi T, Gertner M. Validity of administrative data for characterizing traumatic brain injury-related hospitalizations. Brain Inj. 2005;19:613-21. 


\section{Traumatic Brain Injury in Portugal: Trends in Hospital Admissions from 2000 to 2010 \\ Acta Med Port 2014:27:349-356}

Publicado pela Acta Médica Portuguesa, a Revista Científica da Ordem dos Médicos

Av. Almirante Gago Coutinho, 151

1749-084 Lisboa, Portugal.

Tel: +351 218428215

E-mail: submissao@actamedicaportuguesa.com

www.actamedicaportuguesa.com

ISSN:0870-399X | e-ISSN: 1646-0758

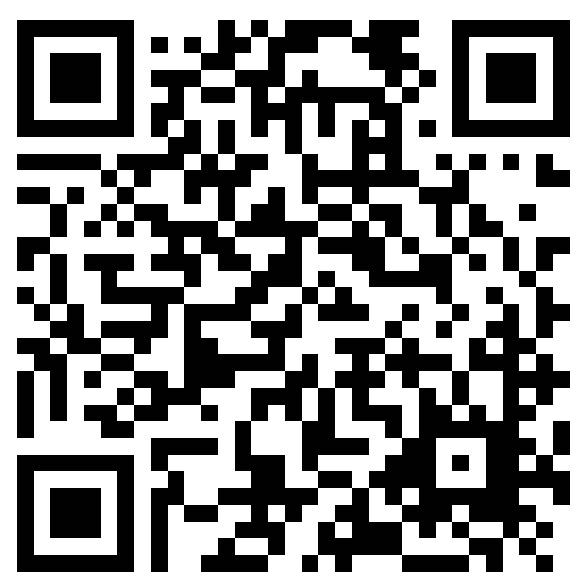

